\title{
Oral health problems among palliative and terminally ill patients: an integrated systematic review
}

\author{
Munikumar Ramasamy Venkatasalu, Zaidah Rizidah Murang, Divya Thirumalai Rajam Ramasamy and \\ Jagjit Singh Dhaliwal
}

\begin{abstract}
Background: High incidence of treatable oral conditions has been reported among palliative patients. However, a large proportion of palliative patients lose their ability to communicate their sufferings. Therefore, it may lead to under-reporting of oral conditions among these patients. This review systematically synthesized the published evidence on the presence of oral conditions among palliative patients, the impact, management, and challenges in treating these conditions.

Methods: An integrative review was undertaken with defined search strategy from five databases and manual search through key journals and reference list. Studies which focused on oral conditions of palliative patients and published between years 2000 to 2017 were included.

Results: Xerostomia, oral candidiasis and dysphagia were the three most common oral conditions among palliative patients, followed by mucositis, orofacial pain, taste change and ulceration. We also found social and functional impact of having certain oral conditions among these patients. In terms of management, complementary therapies such as acupuncture has been used but not well explored. The lack of knowledge among healthcare providers also posed as a challenge in treating oral conditions among palliative patients.

Conclusions: This review is first in its kind to systematically synthesize the published evidence regarding the impact, management and challenges in managing oral conditions among palliative patients. Although there is still lack of study investigating palliative oral care among specific group of patients such as patients with dementia, geriatric or pediatric advanced cancer patients, this review has however provided baseline knowledge that may guide health care professionals in palliative settings.
\end{abstract}

Keywords: Oral conditions, Oral diseases, Palliative, Terminally-ill, Cancer, Integrated review

\section{Introduction}

High incidence of oral conditions were often reported among palliative patients either direct or indirect primary cause such as salivary gland dysfunction in non-Hodgkin's lymphoma or fatigue which may affect patient's ability to undertake oral care hygiene [1,2]. Medical management of

\footnotetext{
* Correspondence: jagjit.dhaliwal@ubd.edu.bn

Pengiran Anak Puteri Rashidah Sa'adatul Bolkiah Institute of Health Sciences, Universiti Brunei Darussalam, Bandar Seri Begawan, Brunei Darussalam
}

palliative conditions such as chemotherapy were often reported which can produce oral complications among these patients [2]. For example, the National Cancer Institute at the National Institutes of Health, United States of America reported that $80 \%$ of patients receiving myeloablative chemotherapy will develop oral complications, and palliative drugs such as bisphosphonates and analgesics were associated with oral mucositis and taste disturbance [3].

(c) The Author(s). 2020 Open Access This article is licensed under a Creative Commons Attribution 4.0 International License, which permits use, sharing, adaptation, distribution and reproduction in any medium or format, as long as you give appropriate credit to the original author(s) and the source, provide a link to the Creative Commons licence, and indicate if changes were made. The images or other third party material in this article are included in the article's Creative Commons licence, unless indicated otherwise in a credit line to the material. If material is not included in the article's Creative Commons licence and your intended use is not permitted by statutory regulation or exceeds the permitted use, you will need to obtain permission directly from the copyright holder. To view a copy of this licence, visit http://creativecommons.org/licenses/by/4.0/ The Creative Commons Public Domain Dedication waiver (http://creativecommons.org/publicdomain/zero/1.0/) applies to the data made available in this article, unless otherwise stated in a credit line to the data. 
Early diagnosis and treatment of oral conditions among palliative patients could minimize their pain and suffering [2]. However, evidence shows that $40 \%$ of palliative patients lose their ability to communicate their oral health needs. Therefore, they may suffer treatable oral conditions for a prolonged period of time [4], or they may not complain of discomfort in their oral cavity which they believe to be an inevitable effect of their treatment [5]. This may contribute to under-reporting as well as underestimation of oral conditions among palliative patients, which may result in failure among health professionals to completely appreciate the problem. A literature review of oral care for cancer patients in 2001 reported that oral care is given by junior staffs with less experience and the practice needs to be transferred to oncology nurses [6]. Furthermore, a survey of international supportive health care providers $(n=212)$ (with $35 \%$ response rate) recommended to develop evidencebased practice protocol for oral care management [7].

This systematic review aimed to synthesize the published evidence on oral conditions among palliative patients, impact, management and challenges in managing oral conditions among palliative patients.

\section{Materials and methods}

\section{Data sources}

Search strategy was devised by the research team with chosen five databases in specific period in English language with comprehensive search terms to not omit any relevant potential primary studies. The detailed data sources are explained in Table 1.

\section{Study selection}

Inclusion criteria specified that studies must be: (1) in full-text, (2) published between years 2000 to 2017, and (3) primary articles focusing on palliative patients and their oral conditions.

Figure 1 illustrates Preferred Reporting Items for Systematic Reviews and Meta-Analyses (PRISMA) flow chart of study selection process [8]. The initial combined search identified 25,311 articles from 5 databases and from other sources (manual searching and through references). Removal of duplicates resulted in 13,263 studies. Screening of relevant abstracts resulted in 1230 studies. Further screening for inclusion criteria resulted in 67 studies which were read to ensure applicability to our study. This resulted in 28 articles being excluded. All reviewers screened and discussed preliminary findings to reach a consensus on studies to be included that resulted in total of 19 articles for further analysis.

\section{Data extraction}

In the data extraction process [9], study details were extracted into a table (Table 1). This was done by two reviewers (Z.R., and D.R.). All reviewers discussed each article to reach consensus regarding the study details. For each included study, the following information was extracted: author(s), year published, title, purpose, setting, participants, study design, and oral conditions present. The impact, management and challenges of oral problems among palliative patients were also extracted and summarized according to our research questions.

\section{Assessment of study quality}

As our review included both qualitative and quantitative studies, we did not use any scoring for assessing the quality of studies included. Rather, the quality of the identified studies was assessed using Joanna Briggs Institute (JBI) critical appraisal tool [10]. As a result, only studies that were thoroughly appraised (have clearly defined inclusion criteria, study subjects and setting described in detail, exposure measured in a valid and reliable way, standard criteria used for measurement of condition, identification of confounding factors, outcomes measured in a valid and reliable way, and appropriate statistical analysis used) and agreed by all involved reviewers were included in this systematic review to write the findings.

Table 1 Details of data sources

\begin{tabular}{|c|c|}
\hline $\begin{array}{l}\text { Research } \\
\text { team }\end{array}$ & $\begin{array}{l}\text { A palliative nurse (MRV) } \\
\text { A dentist (JSD) } \\
\text { A medical doctor (DR) } \\
\text { A healthcare researcher (ZR) }\end{array}$ \\
\hline Data bases & Sciencedirect, PubMed, Google scholar, Ovid and EBSCOhost \\
\hline $\begin{array}{l}\text { Other } \\
\text { resources }\end{array}$ & Reference list and manual search in key journals \\
\hline Search time & January 2000 to December 2017 \\
\hline Language & Primary studies in English language \\
\hline Search terms & $\begin{array}{l}\text { "oral condition" OR "oral disease" OR "dental disease" OR "mouth disease" OR "mouth condition" OR mucositis OR stomatitis OR } \\
\text { candidiasis OR cheilitis OR xerostomia OR "periodontal disease" OR halitosis OR thrush OR "angular cheilitis" OR "denture stomatitis" } \\
\text { OR gingivitis OR periodontitis OR "mouth ulcer" OR "aphthous ulcer" AND palliative OR terminally-ill OR "terminally ill" OR "advanced } \\
\text { disease" OR "advanced illness" OR dying OR end-of-life OR hospice OR cancer AND treatment OR intervention OR therapy OR man- } \\
\text { agement OR "oral care" OR "mouth care" OR "dental management" AND "end-of-life care" }\end{array}$ \\
\hline
\end{tabular}




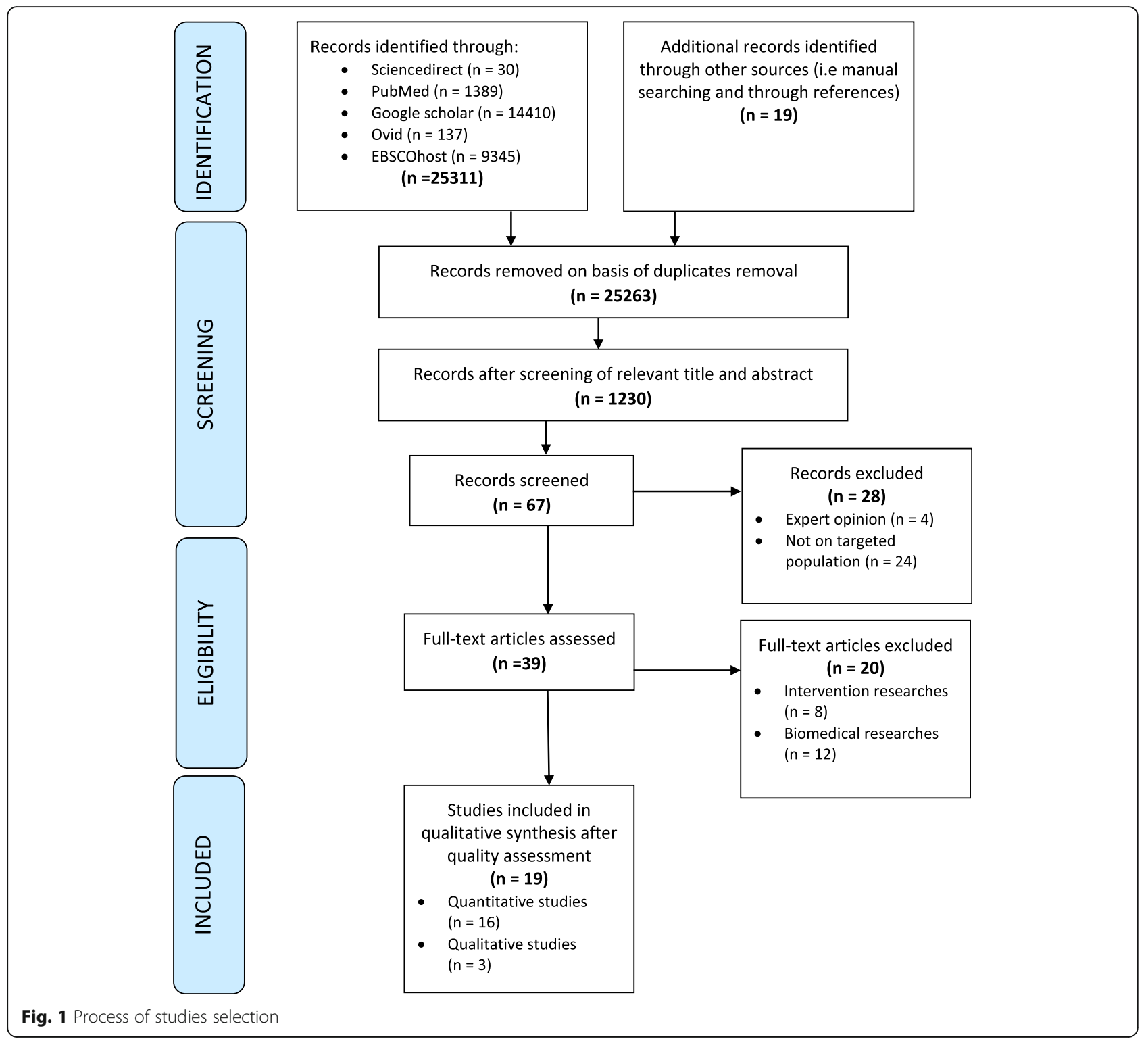

\section{Data analysis}

Extracted data from all included studies were analyzed using the Whittemore and Knafl [9] principles of integrative review with four stages: data reduction, data display, data comparison, and conclusion and verification. At data reduction stage, all 19 primary sources included in the integrative review were divided into subgroups; initially based on types of study (qualitative and quantitative), sample (cancer patients, non-malignant palliative conditions and oral conditions among palliative patients) and then by a predetermined conceptual classification aligning with the aims of this review and then analyzed by topic. Each primary source was reduced to a single page (available on request from authors). This helped us to systematically compare primary sources on specific issues, variables and sample characteristics. It also allowed us to organize the data into a manageable framework. At stage 2 (data display), the single page data from the 19 included studies was extracted and displayed in the form of a table (see Table 1). This helped us to visualize the patterns and relationships between and within primary data sources. At stage 3 (data comparison), we used constant comparison as a method of an iterative process of examining data to identify themes that had similar patterns and relations. Finally at stage 4 (conclusion and verification), patterns using primary data were verified and any similarities, differences and any spurious findings were identified, in order to ensure that valuable information was not lost. Five consecutive meetings were held in order to identify and reach a consensus on the final themes. 
Table 2 Summary of included studies

\begin{tabular}{|c|c|c|c|c|c|c|}
\hline $\begin{array}{l}\text { Author(s)/ } \\
\text { Year }\end{array}$ & Title & Purpose & Setting & Participants & $\begin{array}{l}\text { Study } \\
\text { design }\end{array}$ & $\begin{array}{l}\text { Oral conditions } \\
\text { present }\end{array}$ \\
\hline $\begin{array}{l}\text { Nakajima } \\
\text { /2017 }\end{array}$ & $\begin{array}{l}\text { Characteristics of Oral } \\
\text { Problems and Effects of Oral } \\
\text { Care in Terminally III Patients } \\
\text { With Cancer }\end{array}$ & $\begin{array}{l}\text { To investigate oral problems in } \\
\text { terminal stage of cancer and } \\
\text { improvement of dry mouth by } \\
\text { oral care. }\end{array}$ & Japan & $\begin{array}{l}\text { Terminally-ill cancer } \\
\text { patients }\end{array}$ & $\begin{array}{l}\text { Quantitative } \\
\text { descriptive }\end{array}$ & $\begin{array}{l}\text { 1. Dry mouth } \\
\text { 2. Stomatitis } \\
\text { 3. Candidiasis }\end{array}$ \\
\hline $\begin{array}{l}\text { Fischer } \\
\text { et al./2014 }\end{array}$ & $\begin{array}{l}\text { Oral health conditions affect } \\
\text { functional and social activities } \\
\text { of terminally ill cancer } \\
\text { patients }\end{array}$ & $\begin{array}{l}\text { To characterize oral conditions in } \\
\text { terminally ill cancer patients to } \\
\text { determine the presence, severity, } \\
\text { and the functional and social } \\
\text { impact of these oral conditions. }\end{array}$ & $\begin{array}{l}\text { United } \\
\text { States of } \\
\text { America }\end{array}$ & $\begin{array}{l}\text { Terminally-ill cancer } \\
\text { patients }\end{array}$ & $\begin{array}{l}\text { Quantitative } \\
\text { descriptive }\end{array}$ & $\begin{array}{l}\text { Using } \\
\text { standardized } \\
\text { oral } \\
\text { examination: } \\
\text { 1. Salivary } \\
\text { hypofunction } \\
\text { 2. Mucosal } \\
\text { erythema } \\
\text { 3. Ulceration } \\
\text { 4. Fungal } \\
\text { infection } \\
\text { Using Oral } \\
\text { Problem Scale } \\
\text { (OPS): } \\
\text { 1. Xerostomia } \\
\text { 2. Orofacial } \\
\text { pain } \\
\text { 3. Taste } \\
\text { change }\end{array}$ \\
\hline $\begin{array}{l}\text { Amodio } \\
\text { et al./2014 }\end{array}$ & $\begin{array}{l}\text { Oral health after breast cancer } \\
\text { treatment in postmenopausal } \\
\text { women }\end{array}$ & $\begin{array}{l}\text { To characterize oral health in } \\
\text { postmenopausal breast cancer } \\
\text { survivors. }\end{array}$ & Brazil & $\begin{array}{l}\text { Post-menopausal } \\
\text { breast cancer } \\
\text { survivors }\end{array}$ & $\begin{array}{l}\text { Quantitative } \\
\text { descriptive }\end{array}$ & $\begin{array}{l}\text { 1. Chronic } \\
\text { periodontal } \\
\text { disease }\end{array}$ \\
\hline $\begin{array}{l}\text { Qutob et al. } \\
/ 2013\end{array}$ & $\begin{array}{l}\text { Implementation of a hospital } \\
\text { oral care protocol and } \\
\text { recording of oral mucositis in } \\
\text { children receiving cancer } \\
\text { treatment }\end{array}$ & $\begin{array}{l}\text { To implement a standardized } \\
\text { hospital oral care protocol and } \\
\text { record the incidence of oral } \\
\text { mucositis for inpatients with } \\
\text { childhood cancer. }\end{array}$ & Australia & $\begin{array}{l}\text { Pediatric patients } \\
\text { with cancer }\end{array}$ & $\begin{array}{l}\text { Quantitative } \\
\text { descriptive }\end{array}$ & 1. Mucositis \\
\hline $\begin{array}{l}\text { Velten } \\
\text { et al./2017 }\end{array}$ & $\begin{array}{l}\text { Prevalence of oral } \\
\text { manifestations in children } \\
\text { and adolescents with cancer } \\
\text { submitted to chemotherapy }\end{array}$ & $\begin{array}{l}\text { To evaluate changes in oral } \\
\text { lesions during follow-up of chil- } \\
\text { dren and adolescents in } \\
\text { chemotherapy }\end{array}$ & Brazil & $\begin{array}{l}\text { Children and } \\
\text { adolescents with } \\
\text { cancer }\end{array}$ & $\begin{array}{l}\text { Quantitative } \\
\text { descriptive }\end{array}$ & $\begin{array}{l}\text { 1. Mucositis } \\
\text { 2. Xerostomia } \\
\text { 3. Cold sores } \\
\text { 4. Candidiasis }\end{array}$ \\
\hline $\begin{array}{l}\text { Ezenwa } \\
\text { et al./2016 }\end{array}$ & $\begin{array}{l}\text { Caregivers' perspectives on } \\
\text { oral health problems of end- } \\
\text { of-life cancer patients }\end{array}$ & $\begin{array}{l}\text { To determine caregivers' } \\
\text { perspectives on oral health } \\
\text { problems in cancer patients at } \\
\text { the end of life and explore } \\
\text { factors that contribute to those } \\
\text { perspectives. }\end{array}$ & $\begin{array}{l}\text { United } \\
\text { States of } \\
\text { America }\end{array}$ & $\begin{array}{l}\text { Advanced cancer } \\
\text { patients }\end{array}$ & $\begin{array}{l}\text { Quantitative } \\
\text { descriptive }\end{array}$ & $\begin{array}{l}\text { 1. Xerostomia } \\
\text { 2. Orofacial } \\
\text { pain } \\
\text { 3. Taste } \\
\text { change }\end{array}$ \\
\hline $\begin{array}{l}\text { Mercadante } \\
\text { et al./2015 }\end{array}$ & $\begin{array}{l}\text { Prevalence of oral mucositis, } \\
\text { dry mouth, and dysphagia in } \\
\text { advanced cancer patients. }\end{array}$ & $\begin{array}{l}\text { To determine the prevalence and } \\
\text { the characteristics of oral } \\
\text { symptoms in a large population } \\
\text { of advanced cancer patients. }\end{array}$ & Argentina & $\begin{array}{l}\text { Advanced cancer } \\
\text { patients }\end{array}$ & $\begin{array}{l}\text { Quantitative } \\
\text { descriptive }\end{array}$ & $\begin{array}{l}\text { 1. Mucositis } \\
\text { 2. Dry mouth } \\
\text { 3. Dysphagia }\end{array}$ \\
\hline $\begin{array}{l}\text { Matsuo } \\
\text { et al./2016 }\end{array}$ & $\begin{array}{l}\text { Associations between oral } \\
\text { complications and days to } \\
\text { death in palliative care } \\
\text { patients }\end{array}$ & $\begin{array}{l}\text { To investigate the associations } \\
\text { between the incidence of oral } \\
\text { problems and the days to death } \\
\text { (DTD) in patients receiving } \\
\text { palliative care. }\end{array}$ & Japan & $\begin{array}{l}\text { Patients receiving } \\
\text { palliative care }\end{array}$ & $\begin{array}{l}\text { Quantitative } \\
\text { descriptive }\end{array}$ & $\begin{array}{l}\text { 1. Dental caries } \\
\text { 2. Gingival } \\
\text { inflammation } \\
\text { 3. Tongue } \\
\text { coating } \\
\text { 4. Candidiasis } \\
\text { 5. Tongue } \\
\text { inflammation } \\
\text { 6. Dry mouth } \\
\text { 7. Bleeding } \\
\text { spots }\end{array}$ \\
\hline $\begin{array}{l}\text { Kvalheim } \\
\text { et al./2016 }\end{array}$ & $\begin{array}{l}\text { End-of-life palliative oral care } \\
\text { in Norwegian health } \\
\text { institutions. An exploratory } \\
\text { study. }\end{array}$ & $\begin{array}{l}\text { To explore circumstances } \\
\text { surrounding procedures and } \\
\text { knowledge regarding oral care } \\
\text { for terminal patients in } \\
\text { Norwegian healthcare } \\
\text { institutions. }\end{array}$ & Norway & $\begin{array}{l}\text { Nurses for end-of-life } \\
\text { patients }\end{array}$ & $\begin{array}{l}\text { Quantitative } \\
\text { descriptive }\end{array}$ & $\begin{array}{l}\text { 1. Dry mouth } \\
\text { 2. Plaque } \\
\text { 3. Food } \\
\text { particles and } \\
\text { fungus } \\
\text { Infections } \\
\text { 4. Sores and }\end{array}$ \\
\hline
\end{tabular}


Table 2 Summary of included studies (Continued)

\begin{tabular}{|c|c|c|c|c|c|c|}
\hline $\begin{array}{l}\text { Author(s)/ } \\
\text { Year }\end{array}$ & Title & Purpose & Setting & Participants & $\begin{array}{l}\text { Study } \\
\text { design }\end{array}$ & $\begin{array}{l}\text { Oral conditions } \\
\text { present }\end{array}$ \\
\hline & & & & & & $\begin{array}{l}\text { scab } \\
\text { 5. Viscous ropy } \\
\text { saliva and } \\
\text { chapped lips } \\
\text { 6. Reduced } \\
\text { appetite and } \\
\text { pain } \\
\text { 7. Dysphagia } \\
\text { 8. Halitosis } \\
\text { 9. Coughing } \\
\text { and problems } \\
\text { using dentures }\end{array}$ \\
\hline $\begin{array}{l}\text { Bogaardt } \\
\text { et al./2015 }\end{array}$ & $\begin{array}{l}\text { Swallowing problems at the } \\
\text { end of the palliative phase: } \\
\text { incidence and severity in } 164 \\
\text { unsedated patients. }\end{array}$ & $\begin{array}{l}\text { To establish the incidence of } \\
\text { swallowing problems and related } \\
\text { problems in the dying phase }\end{array}$ & Netherlands & Dying patients & $\begin{array}{l}\text { Quantitative } \\
\text { descriptive }\end{array}$ & $\begin{array}{l}\text { 1. Swallowing } \\
\text { problems } \\
\text { 2. Frequent } \\
\text { coughing } \\
\text { 3. Problems } \\
\text { with oral } \\
\text { secretions }\end{array}$ \\
\hline $\begin{array}{l}\text { Meidell } \\
\text { et al./ } 2009\end{array}$ & $\begin{array}{l}\text { Acupuncture as an optional } \\
\text { treatment for hospice } \\
\text { patients with xerostomia: an }\end{array}$ & $\begin{array}{l}\text { To investigate the feasibility of } \\
\text { conducting a 5-week acupunc- } \\
\text { ture intervention in a hospice, }\end{array}$ & Sweden & End-of-life patients & $\begin{array}{l}\text { Quantitative } \\
\text { comparative }\end{array}$ & $\begin{array}{l}\text { 1. Xerostomia } \\
\text { 2. Dysphagia } \\
\text { 3. Dysarthria }\end{array}$ \\
\hline
\end{tabular}

$\begin{array}{llll}\text { Lagman } & \begin{array}{l}\text { Single-Dose Fluconazole } \\ \text { et al./2017 }\end{array} & \begin{array}{l}\text { To assess the efficacy of a single- } \\ \text { Therapy for Oral Thrush in } \\ \text { dose fluconazole } 150 \mathrm{mg} \text { for oral } \\ \text { thrush. }\end{array} & \begin{array}{l}\text { United } \\ \text { States of }\end{array} \\ \text { America }\end{array}$

Momo et al., Assessment of indomethacin 2017 oral spray for the treatment of oropharyngeal mucositisinduced pain during anticancer therapy

$\begin{array}{ll}\begin{array}{ll}\text { Ling \& } \\ \text { Larsson/ }\end{array} & \begin{array}{l}\text { Individualized } \\ \text { pharmacological treatment } \\ \text { Oral mucositis pain in patients } \\ \text { with head and neck cancer } \\ \text { receiving radiotherapy }\end{array} \\ \text { Gligorov } & \begin{array}{l}\text { Prevalence and treatment } \\ \text { et al./2011 }\end{array} \\ & \begin{array}{l}\text { management of } \\ \text { oropharyngeal candidiasis in } \\ \text { cancer patients: results of th } \\ \text { French CANDIDOSCOPE } \\ \text { study. }\end{array} \\ & \begin{array}{l}\text { Oral candidosis in patients } \\ \text { Davies } \\ \text { et al./2006 }\end{array} \\ \text { with advanced cancer }\end{array}$

Wilberg et al./2012
To assess the efficacy and safety of indomethacin (IM) oral spray (OS) as a pain control therapy for oropharyngeal mucositis due to anticancer chemo- and radiotherapy

To assess the effect of pharmacological treatment in head and neck cancer patients with OM-induced pain and swallowing difficulties.

To evaluate the prevalence of oropharyngeal candidiasis (OPC) in cancer patients treated with chemotherapy and/or radiotherapy.

To determine the epidemiology, aetiology, clinical features and microbiological aspects of oral candidosis in a cohort of cancer patients receiving specialist palliative care.

To assess the prevalence of oral morbidity in patients receiving palliative care for cancers outside the head and neck region and to investigate if information concerning oral problems was
Oral health is an important issue in end-of-life cancer care.
Palliative and hospice patients with advanced cancer and have a clinical diagnosis of oral thrush

Japan

Patients with head and neck carcinomas and haematological tumours

Sweden

Patients with head
and neck cancer
undergoing
radiotherapy

France

Cancer patients
treated with
chemotherapy and/or
radiotherapy

United Kingdom

Cancer patients receiving specialist palliative care.

descriptive

Quantitative descriptive Oropharyngeal candidiasis

2. Mucositis

3. Xerostomia

4. Taste

changes 5. Pain

Norway

Cancers patients Qualitative 1. Oral yeast carriage 2. Oral candidiasis 3. Xerostomia outside the head and interview neck region
1. Xerostomia
2. Mucosal
friction
3. General oral
discomfort
4. Taste 
Table 2 Summary of included studies (Continued)

\begin{tabular}{|c|c|c|c|c|c|c|}
\hline $\begin{array}{l}\text { Author(s)/ } \\
\text { Year }\end{array}$ & Title & Purpose & Setting & Participants & $\begin{array}{l}\text { Study } \\
\text { design }\end{array}$ & $\begin{array}{l}\text { Oral conditions } \\
\text { present }\end{array}$ \\
\hline & & given. & & & & $\begin{array}{l}\text { changes } \\
\text { 5. Candidiasis }\end{array}$ \\
\hline $\begin{array}{l}\text { Rydholm \& } \\
\text { Strang/2002 }\end{array}$ & $\begin{array}{l}\text { Physical and psychosocial } \\
\text { impact of xerostomia in } \\
\text { palliative cancer care: a } \\
\text { qualitative interview study }\end{array}$ & $\begin{array}{l}\text { To explore the global effects of } \\
\text { xerostomia, with a specific focus } \\
\text { on psychological and social } \\
\text { consequences. }\end{array}$ & Sweden & $\begin{array}{l}\text { Patients with } \\
\text { advanced } \\
\text { malignancies and } \\
\text { symptomatic } \\
\text { xerostomia }\end{array}$ & $\begin{array}{l}\text { Qualitative } \\
\text { interview }\end{array}$ & $\begin{array}{l}\text { 1. Subjective } \\
\text { discomfort } \\
\text { 2. Dryness or } \\
\text { burning } \\
\text { sensation } \\
\text { 3. Loss of } \\
\text { function e.g. } \\
\text { articulation or } \\
\text { swallowing } \\
\text { 4. Increased } \\
\text { infection (oral } \\
\text { thrush and } \\
\text { ulcerations) }\end{array}$ \\
\hline $\begin{array}{l}\text { Rohr et al./ } \\
2010\end{array}$ & $\begin{array}{l}\text { Oral discomfort in palliative } \\
\text { care: results of an exploratory } \\
\text { study of the experiences of } \\
\text { terminally ill patients. }\end{array}$ & $\begin{array}{l}\text { To examine oral discomfort from } \\
\text { the perspective of terminally ill } \\
\text { patients. }\end{array}$ & Australia & Terminally-ill patients & $\begin{array}{l}\text { Qualitative } \\
\text { interview }\end{array}$ & $\begin{array}{l}\text { 1. Xerostomia } \\
\text { 2. Bouts of } \\
\text { ulceration and } \\
\text { infection }\end{array}$ \\
\hline
\end{tabular}

\section{Results}

\section{Characteristics of study}

Overall, 19 articles were included in this review. The majority of the participants were cancer patients $(n=14)$. Studies reporting on oral conditions among palliative patients are summarized in Table 1 . Of the included studies, 16 were quantitative studies $[5,11-24]$, and 3 were qualitative studies [25-27](Table 2).

\section{Common oral conditions among palliative patients}

Out of 19 studies, 13 reported xerostomia or dryness of mouth [5, 11, 14-17, 19, 23-28]. Eight studies reported candidiasis or oral thrush $[11,14,16,20,23-26]$. Six studies reported dysphagia or swallowing difficulties [15, 17$19,22,26]$. Five reported mucositis [13-15, 21, 22] and 5 orofacial pain $[5,17,22,23,28]$. Four studies reported taste changes $[5,23,25,28]$ and two reported ulceration $[5,26]$, coughing $[17,18]$ and oral discomfort $[25,26]$.

Other oral conditions reported are stomatitis [11], salivary hypofunction [5], mucosal erythema [5], fungal infection [5], periodontitis [12], cold sores [14], dental caries [16], gingival inflammation [16], tongue coating and inflammation [16], bleeding spots [16], plaque [17], food particles and fungus infection [17], sores and scabs [17], viscous ropy saliva and chapped lips [17], halitosis [17], problems using dentures [17], problems with oral secretions [18], dysarthria [19], oral yeast carriage [24], mucosal friction [25], and bouts of ulceration and infection [27].

\section{Multifaceted impact of oral conditions in palliative patients}

Table 3 presents our findings associating the social and functional impact of oral conditions [5, 25-28]. Our review also revealed social and functional impact of having oral conditions among palliative patients. Social impact include feeling worried, bothered, a feeling of less satisfying life, shame, anxiety, depression, increased feelings of being a patient rather than a person, not wanting people to be around them which affected their social interaction and resulted in loneliness [5, 25-28]. Functional impact include difficulties in swallowing, speaking and eating, food restriction, sense of oral dryness and pain, which resulted in lack of food enjoyment $[5,26,28]$.

\section{Management of oral conditions among palliative patients}

Table 4 presents our findings on the management of some oral conditions among palliative patients and their effectiveness [11, 15, 17, 19-23] Our study revealed that the common management options for xerostomia are drug and medical treatments [15], lubricating lips and mucosa [17], acupuncture [19], and standard oral care which improved dry mouth (in $80 \%$ or more) of the patients [11]. For candidiasis, a single-dose fluconazole $150 \mathrm{mg}$ via mouth was found to be very effective as the symptoms decreased significantly $(P<0.001)$ in most patients [20], and local antifungal treatments were reported to be efficacious in $78.1 \%$ of the patients [23]. A substantial improvement of dysphagia was also observed after fifth treatment of acupuncture [19], however, its management using step-based pharmacological intervention and topically acting drugs caused worsening of swallowing and soreness of mouth [22]. Also, the management of mucositis using step-based pharmacological intervention and topically-acting drugs did not improve the oral condition [22], however, an indomethacin oral spray has been proven to relieve pain after $25 \mathrm{~min}$ [21]. 
Table 3 Studies addressing the impact of oral conditions among palliative patients

\begin{tabular}{|c|c|c|}
\hline \multirow[t]{2}{*}{ Study } & \multicolumn{2}{|l|}{ Findings associating oral conditions and its social and/or functional impact } \\
\hline & Social & Functional \\
\hline $\begin{array}{l}\text { Fischer } \\
\text { et al. }\end{array}$ & $\begin{array}{l}\text { Orofacial pain and salivary hypofunction had significant associations } \\
\text { with social impact }(p<0.001) \text { such as worrisome that affected the } \\
\text { patients' social interactions. }\end{array}$ & $\begin{array}{l}\text { Xerostomia }(p<0.001) \text {, orofacial pain }(p<0.001) \text {, salivary } \\
\text { hypofunction }(p<.001) \text { and taste change }(p=0.042) \text { had } \\
\text { significant associations with functional impact, which was possibly } \\
\text { related to food enjoyment. }\end{array}$ \\
\hline $\begin{array}{l}\text { Ezenwa } \\
\text { et al. }\end{array}$ & $\begin{array}{l}\text { Xerostomia, orofacial pain and taste change had social impact of } \\
\text { feeling worried, bothered, not wanting people around and a feeling } \\
\text { of less satisfying life, with percentage agreement ranged from } 41 \text { to } \\
64 \% \text { between caregivers and care recipients. However, a significant } \\
\text { difference in the means of the social impact subscale was reported } \\
\text { between the two groups }(p=0.02) \text {, with caregivers overestimating } \\
\text { social impact. }\end{array}$ & $\begin{array}{l}\text { Xerostomia, orofacial pain and taste change had functional impact } \\
\text { which include swallowing difficulty, speaking difficulty, eating } \\
\text { difficulty, food restriction, dryness and pain, with significant } \\
\text { correlation between caregivers' and care recipients' ratings ( } p< \\
0.001 \text { ) }\end{array}$ \\
\hline $\begin{array}{l}\text { Rydholm } \\
\text { \& Strang }\end{array}$ & $\begin{array}{l}\text { Xerostomia was reported to have psychosocial effects, including } \\
\text { shame, increased feelings of being a patient rather than a person } \\
\text { and a tendency to avoid social contact, resulting in loneliness. }\end{array}$ & $\begin{array}{l}\text { Xerostomia was reported to be associated with loss of oral } \\
\text { function, such as in articulation and swallowing. }\end{array}$ \\
\hline $\begin{array}{l}\text { Rohr } \\
\text { et al. }\end{array}$ & $\begin{array}{l}\text { Orofacial pain prevent patient from sharing and enjoying meals with } \\
\text { friends and family, which limit their social outings and participation } \\
\text { at special occasions. Participants were more 'tentative' in holding a } \\
\text { conversation with others due to speech difficulties, hence avoiding } \\
\text { 'close physical contact' with their loved ones. }\end{array}$ & $\begin{array}{l}\text { Xerostomia was described as 'constantly } \\
\text { there', causing swallowing difficulties and loss of taste. Difficulty of } \\
\text { swallowing was also described as 'unbearable at times'. }\end{array}$ \\
\hline $\begin{array}{l}\text { Wilberg } \\
\text { et al. }\end{array}$ & $\begin{array}{l}\text { Xerostomia and taste alterations were associated with anxiety }(p= \\
0.04) \text { and depression }(p=0.34)\end{array}$ & $\mathrm{n} / \mathrm{a}$ \\
\hline
\end{tabular}

${ }^{*} n / a$ not available

\section{Treatment challenges of oral conditions in palliative patients}

Table 5 presents our findings on the challenges in treating oral conditions among palliative patients [17, 18]. Only 2 of the included papers addressed the challenges in treating oral conditions among palliative patients. Kvalheim et al. (2016) found that some of the challenges were the lack of knowledge/routine, patient cooperation, resources, priority given to oral problems, as well as difficulty in accessing the mouth and retching. Bogaardt et al. (2015) observed underestimation of reported oral problems among palliative patients by rating significantly lower incidence and severity problems by the nursing staff compared to the patients' relatives.

\section{Discussion}

To our knowledge, this review is first of its kind to systematically and comprehensively synthesize the published evidence on oral conditions among palliative patients, impact, management and challenges in the management. Our review found that the most common oral conditions among palliative patients are xerostomia, oral candidiasis, dysphagia, mucositis, orofacial pain, taste change and ulceration. A previous study by Saini et al. (2009) has also stated xerostomia, oral candidiasis, mucositis, dysphagia, ulceration, taste disorders and pain as the most common oral problems among palliative patients [2]. Another discussion paper on oral cavity complications of patients with advanced cancer also found that xerostomia, oral candidiasis and taste alterations are very common among these patients which could lead to malnutrition and communication disorder [29]. In addition, Mulk et al. (2014) described the role of dentist in palliative team and categorized xerostomia and trouble in swallowing as the indication of terminal phase of life [30]. Chen (2015) proposed an oral health care model for seriously-ill old people and stated that xerostomia is a major problem in all dying stages (decline, pre-active dying and actively dying) which worsen with each stage due to kidney failure, dehydration, and the use of anticholinergic medications during the actively dying phase [31].

Our review also revealed social and functional impact of having certain oral conditions among palliative patients. In agreement, Saini et al. (2009) stated that oral lesions have an immense impact on the quality of life of patients with complex advanced diseases, causing considerable morbidity to patient's physical condition due to reduced oral intake and weight loss, as well as psychological well-being due to impaired communication and feelings of exclusion and social isolation. Mulk et al. (2014) explained that the most common psychological problem for the elderly requiring a palliative approach is depression, and due to the lack of proper oral hygiene among depressed patients, they often present with halitosis (bad breath) which may cause people around them to stay away from them, causing severe social impact among these patients.

Our review also reported various treatment options for several oral conditions. For example, using salivary substitutes for xerostomia, and using fluconazole for candidiasis, and its effectiveness among palliative patients. 
Table 4 Studies addressing the management of oral conditions among palliative patients

\begin{tabular}{|c|c|c|c|}
\hline $\begin{array}{l}\text { Oral } \\
\text { condition }\end{array}$ & Study & Management & Effectiveness \\
\hline \multirow[t]{2}{*}{ Xerostomia } & $\begin{array}{l}\text { Mercadante } \\
\text { et al. }\end{array}$ & $\begin{array}{l}\text { Drug medication } \\
\text { - Opioids } \\
\text { - Corticosteroids } \\
\text { - Diuretics } \\
\text { - Benzodiazepines } \\
\text { - Anticonvulsants } \\
\text { - Neuropletics } \\
\text { - Nonsteroidal anti-inflammatory drugs } \\
\text { Medical treatment } \\
\text { - Chlorexidine } \\
\text { - antifungal drugs } \\
\text { - Benzydamine } \\
\text { - Natural agents }\end{array}$ & $n / a$ \\
\hline & $\begin{array}{l}\text { Kvalheim } \\
\text { et al. }\end{array}$ & $\begin{array}{l}\text { Lubricating lips } \\
\text { - Eucerin liniment } \\
\text { - Glycerol } \\
\text { - Vaseline } \\
\text { - Blisex } \\
\text { - Lypsyl } \\
\text { - Lip stick } \\
\text { - Lip cream } \\
\text { Lubricating mucosa } \\
\text { - Glycerol } \\
\text { - Glycerol solution 17\% } \\
\text { - Glycerol solution 50\% } \\
\text { - Glycerol solution 70\% } \\
\text { - Glycerol with peppermint oil } \\
\text { - Glycerol and Chlorhexidine } \\
\text { - Xylocaine/Lidocaine viscous } \\
\text { - Xylocaine/Lidocaine viscous } \\
\text { - Paracetamol mixture and cream } \\
\text { - Panodil mixture and cream 1:1 } \\
\text { - Pure cream } \\
\text { - Zendium saliva } \\
\text { - Zendium gel } \\
\text { - Groundnut oil } \\
\text { - Saliva gel } \\
\text { - Oralbalance } \\
\text { - Mouth moisturiser }\end{array}$ & $\mathrm{n} / \mathrm{a}$ \\
\hline
\end{tabular}

Meidell \& Acupuncture treatment twice a week for 5 weeks - a total Rasmussen of ten treatments.
Nakajima Standard oral care by nursing staff of the wards, which include moisturizing, brushing, and oral cleaning (such as tongue coating removal) or oral massage performed by ward staff on a regular basis to resolve dry mouth). Intervention by specialist oral care team (specialist oral care) was performed as needed.
Measurements were using visual analogue scale (VAS), consisted of a horizontal line, $0-10 \mathrm{~cm}$, where 0 represented no problem or discomfort and 10 represented severe problems and discomfort. The feeling of dryness of the mouth declined for all the participants as the series of treatment proceeded. In most cases a substantial improvement could not be noted until after fifth treatments. VAS decreased from 7.5 to 4.8 after fifth treatments $(P<$ 0.001). Between the sixth and tenth treatments, the VAS decreased from 4.8 to $3.3(P<0.001)$. The VAS decreased from 7.5 before the baseline to 3.3 before the tenth treatment $(P<0.001)$.

The rate of dry mouth improvement by oral care intervention was investigated by the severity (Grade 1,2 and 3).

All grade 1 cases were improved by standard oral care (100\%). Grade 2 dry mouth was improved by standard oral care in $85 \%$ in good oral intake group (oral food intake was $30 \%$ or more) and $71 \%$ in poor oral intake group (oral food intake was less than 30\%). Six ineffective cases of poor oral intake group were treated with specialist oral care, resulting in an improvement rate of $83 \%$.

Grade 3 dry mouth was improved by standard oral care in $40 \%$ in good oral intake group, and 2 ineffective cases were treated with specialist oral care, resulting in an improvement rate of $80 \%$. In poor oral intake group, improvement was achieved by standard oral care in $67 \%$, 
Table 4 Studies addressing the management of oral conditions among palliative patients (Continued)

\begin{tabular}{ll}
\hline $\begin{array}{l}\text { Oral Study } \\
\text { condition }\end{array}$ & Management \\
\hline & \\
Candidiasis Lagman & A single-dose fluconazole $150 \mathrm{mg}$ via mouth \\
& et al.
\end{tabular}
et al.

Gligorov et al.

Ling \& Step-based pharmacological intervention

Larsson
1. Acetaminophen
2. NSAID
3. Opioids
4. Adjuvant medication

- Amitryptilin, gabapentin, or pregabalin were considered due to neurotic pain, mainly tumor-related.

- Betametasone was considered for optimized antiinflammatory effect, impaired general condition, or antiemetic effect.

Topically acting drugs

- Lidocain and benzydamine were prescribed at RT start by the dental services at the hospital to all patients with an irradiated mouth.

Mucositis Ling \& Larsson

Step-based pharmacological intervention

1.Acetaminophen

2.NSAID

3.Opioids

4.Adjuvant medication

- Amitryptilin, gabapentin, or pregabalin were considered due to neurotic pain, mainly tumor-related.

- Betametasone was considered for optimized antiinflammatory effect, impaired general condition, or antiemetic effect.

Topically acting drugs

Lidocain and benzydamine were prescribed at RT start by the dental services at the hospital to all patients with an irradiated mouth.

Momo et al. Indomethacin (IM) oral spray (OS)
Effectiveness

and 8 ineffective cases were treated with specialist oral care, resulting in an improvement rate of $81 \%$.

Thus, these interventions improved dry mouth in $80 \%$ or more

of the patients both in good oral intake group and in poor oral

intake group.

Majority had complete response, except 2 who did not respond to treatment. Probable side effects of the medication included nausea in 4 patients, abdominal pain in 1 , and diarrhea in 1 . Both the change in the number of symptoms and the symptom scores before and after treatment decreased significantly $(P<0.001)$.

Miconazole MBT was reported to be "efficacious" or "very efficacious" in 25 of 32 patients (78.1\%) vs. 39 of 51 (76.5\%) for amphotericin B, and 9 of 15 60\%)

for nystatin. The nonefficacy reported by the patients was related to noncompliance to treatment; $30 \%$ of noncompliant patients vs. $14.3 \%$ of those compliant rated amphotericin B as "slightly efficacious or not efficacious."

Measurements were using visual analogue scale (VAS), consisted of a horizontal line, $0-10 \mathrm{~cm}$, where 0 represented no problem or discomfort and 10 represented severe problems and discomfort. A substantial improvement of dysphagia was

not obvious until after fifth treatments when the

VAS had decreased from 5.6 to 4.1 ( $P<0.001)$. Between the sixth and tenth treatments, the VAS decreased from 4.1 to $3.7(P=0.81)$. The VAS decreased from 5.6 before the baseline to 3.7 before the tenth treatment $(P=0.01)$.

Soreness in the mouth showed unexpectedly significant worsening $(P=0.001)$ between baseline (TQ1) and 1 week later (TQ2).

Significant worsening was found for three swallowing questions about liquids $(P=0.007)$ and solid food $(P=0.004)$ choking when swallowing $(P=0.018)$.

Four oral mucositis (OM) grades were used: 0 : No reaction

1: Hyperaemia, impressions, soreness, edema

2: Erythema, occasional ulcers, soreness

3: Painful erythema, larger fibrin-coated ulcers

4: Widespread ulcerated areas, easily bleeding, very painful In the early intervention (EI) group, the OM grade increased between baseline (TQ1) and 1 week later (TQ2) $(P<0.001)$. In the late intervention (LI) group, the OM grade was unchanged between TQ1 and TQ2 $(P=0.059)$.

Pain relief was achieved in 93\% patients at 25 (5-60) min after applying the IM-OS preparation $(15.6 \pm 3.4 \mu \mathrm{g} / \mathrm{kg})$ and 
Table 4 Studies addressing the management of oral conditions among palliative patients (Continued)

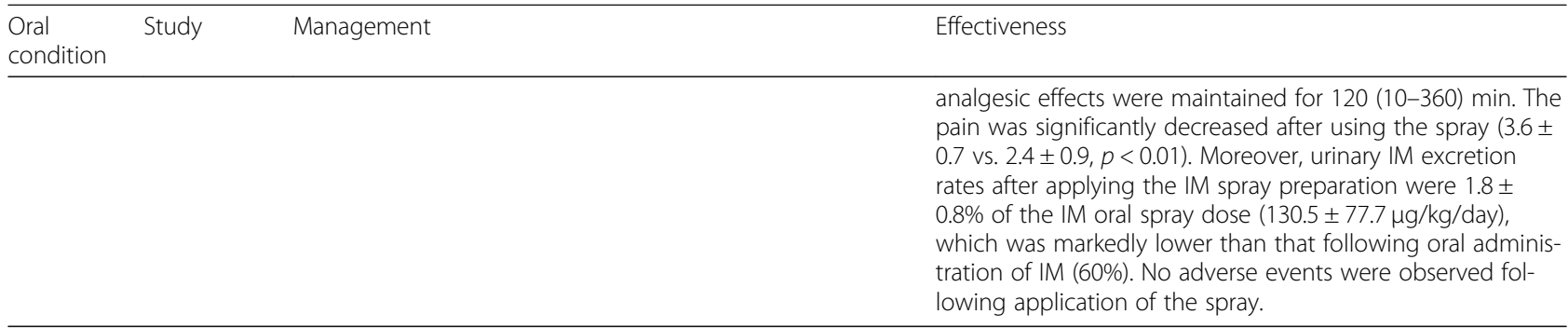

${ }^{*} n / a$ not available

Saini et al. (2009) also reported similar treatment options for some oral conditions as in the present study, they highlighted that one of the management option for dysphagia is to remove coating or plaque from teeth, and removal of dental prosthesis to clean and rectify for any technical error for mucositis, whilst emphasizing that the management of oral problems in palliative patients should be carried out as a team work and treatment protocol should be available to guide non-dentist and dental expert. On the other hand, a clinical paper on the management of oral mucositis in cancer patients found that the current clinical management of mucositis is largely focused on palliative measures such as pain management, nutritional support and maintenance of good oral hygiene, with several promising therapeutic agents in various stages of clinical development [32]. However, none of the studies mentioned complimentary therapies such as acupuncture as a treatment option neither for xerostomia and dysphagia nor any oral conditions among palliative patients.

Our review also highlights that the lack of knowledge among healthcare providers posed a challenge in treating oral conditions among palliative patients. A study reported that training and involvement of dental professionals in caring for palliative patients seem to remain limited [33]. On the other hand, evidence also report that patients and their families are less likely to prioritize oral care needs due to increased diseases burden, transportation difficulties and psychological distress at the

Table 5 Studies addressing the challenges in treating oral conditions among palliative patient

\begin{tabular}{ll}
\hline Study & Challenges \\
\hline Kvalheim & - Lack of knowledge/experience/routine (43\%) \\
et al. & - Lack of patient cooperation (38\%) \\
& - Oral problems were not prioritised (22\%) \\
& - Difficult access to the mouth $(11 \%)$, \\
& - Lack of resources by (8\%) \\
& - Retching (3\%). \\
Bogaardt & Nursing staff rated the incidence and severity \\
et al & of swallowing problems lower than the relatives \\
& - Nursing staff rated the median severity of frequent \\
& coughing $(p=0.012)$ and loss of appetite $(p=0.001)$ \\
& significantly lower compared to the relatives'
\end{tabular}

end of life [4]. This study also found patient cooperation as a challenge in treating oral conditions among palliative patients as it was explained that is due to the process of transferring palliative patients to dental offices for oral examination and treatment that could be physically challenging and stressful for these patients.

Apart from the above, it can be seen that among the scientific articles included in the literature review, two papers are concerning head and neck cancer patients [21], which may be more significant on the patient's oral well-being conditions, both for the localization of the tumor and the regional radiotherapy. Therefore, future reviews can focus on patients with specific types of cancer and their oral conditions. This would greatly contribute to the body of knowledge on palliative care. Regardless, our review has provided baseline knowledge that can guide health care professionals in palliative settings.

\section{Conclusion}

This review summarizes the diverse oral conditions that challenge the quality of life of palliative patients. Evidence is emerging on various treatment options for management of oral conditions among diverse palliative conditions. Our review also highlights the lack of evidence investigating palliative oral care among specific group of patients such as patients with dementia, geriatric or pediatric advanced cancer patients. Yet, this review provides baseline comprehensive knowledge and practice of quality oral care for palliative patients that may guide health care professionals in palliative settings.

\section{Abbreviations}

PRISMA: Preferred Reporting Items for Systematic Reviews and MetaAnalyses; JBl: Joanna Briggs Institute

\section{Acknowledgements}

We would like to thank Universiti Brunei Darussalam for the award of a grant that makes this project possible.

Authors' contributions

ZR prepared the drafts of this paper, interpreted and analyzed the data. MRV, DTR and JSD commented for improvement in writing. All authors read and approved the final manuscript. 


\section{Funding}

Universiti Brunei Darussalam; Grant information: UBD/OAVCRI/CRGWG (014)/ 171001.

\section{Availability of data and materials}

The datasets used for the current study are available from the corresponding author on reasonable request.

\section{Ethics approval and consent to participate}

Not applicable.

\section{Consent for publication}

Not applicable.

\section{Competing interests}

The authors declare that they have no competing interests.

Received: 15 March 2019 Accepted: 11 March 2020

Published online: 18 March 2020

\section{References}

1. Ohno T, Morita T, Tamura F, et al. The need and availability of dental services for terminally ill cancer patients: a nationwide survey in Japan. Support Care Cancer. 2016;24:19-22.

2. Saini $R$, Marawar $P$, Shete $S$, et al. Dental expression and role in palliative treatment. Indian J Palliat Care. 2009;15:26-9.

3. Epstein J. Oral Complications of Cancer and Its Management - Joel Epstein Google Books, https://books.google.com.bn/books?id=HNnWIYX5AngC\&pg= PA3\&lpg=PA3\&dq=DIRECT+INDIRECT+CAUSE+OF+PALLIATIVE+ORAL + CONDITIONS\&source=bl\&ots=HsVdvae7yz\&sig=OaCazVj0wB4mBsbaNS44 H8OL-Go\&hl=en\&sa=X\&ved=2ahUKEwi v47HzareAhUKwrwKHSOqBU8Q6 AEwC3oECAIQAQ\#V=onepage\&q=DIR (accessed 29 Oct 2018).

4. Chen $\mathrm{X}$, Chen $\mathrm{H}$, Douglas $\mathrm{C}$, et al. Dental treatment intensity in frail older adults in the last year of life. J Am Dent Assoc. 2013;144:1234-42.

5. Fischer DJ, Epstein JB, Yao Y, et al. Oral health conditions affect functional and social activities of terminally ill cancer patients. Support Care Cancer. 2014;22:803-10

6. Miller M, Kearney N. Oral care for patients with cancer: a review of the literature. Cancer Nurs. 2001;24:241-54.

7. Barker GJ, Epstein JB, Williams KB, et al. Current practice and knowledge of oral care for cancer patients: a survey of supportive health care providers. Support Care Cancer. 2005;13:32-41.

8. Moher D, Liberati A, Tetzlaff J, et al. Guidelines and guidance preferred reporting items for systematic reviews and meta-analyses: the PRISMA statement. PLoS Med. 2009:6:e1000097.

9. Whittemore R, Knafl K. The integrative review: updated methodology. J Adv Nurs. 2005:52:546-53.

10. Checklist for Analytical Cross Sectional Studies Critical Appraisal Checklist for Analytical Cross Sectional Studies 2, http://joannabriggs.org/research/criticalappraisal-tools.htmlwww.joannabriggs.org (2017, accessed 19 Nov 2018).

11. Nakajima N. Characteristics of Oral problems and effects of Oral Care in Terminally ill Patients with Cancer. Am J Hosp Palliat Med. 2017;34:430-4.

12. Amodio J, Palioto D, Carrara H, et al. Oral health after breast cancer treatment in postmenopausal women. Clinics. 2014;69:706-8.

13. Qutob AF, Allen $G$, Gue $S$, et al. Implementation of a hospital oral care protocol and recording of oral mucositis in children receiving cancer treatment : a retrospective and a prospective study. Support Care Cancer. 2013:21:1113-20.

14. Velten DB, Zandonade E, Monteiro de Barros Miotto MH. Prevalence of oral manifestations in children and adolescents with cancer submitted to chemotherapy. BMC Oral Health. 2017;17:49.

15. Mercadante S, Aielli F, Adile C, et al. Prevalence of oral mucositis, dry mouth, and dysphagia in advanced cancer patients. Support Care Cancer. 2015;23:3249-55.

16. Matsuo K, Watanabe R, Kanamori D, et al. Associations between oral complications and days to death in palliative care patients. Support Care Cancer. 2016;24:157-61.

17. Kvalheim SF, Strand GV, Husebø BS, et al. End-of-life palliative oral care in Norwegian health institutions. An exploratory study. Gerodontology. 2016; 33:522-9.
18. Bogaardt H, Veerbeek L, Kelly K, et al. Swallowing problems at the end of the palliative phase: incidence and severity in 164 unsedated patients. Dysphagia. 2015;30:145-51.

19. Meidell $L$, Holritz RB. Acupuncture as an optional treatment for hospice patients with xerostomia: an intervention study. Int J Palliat Nurs. 2009;15:12-20.

20. Lagman R, Davis M, LeGrand $\mathrm{S}$, et al. Single-dose fluconazole therapy for Oral thrush in hospice and palliative medicine patients. Am J Hosp Palliat Care. 2017:34:645-9.

21. Momo K, Nagaoka H, Kizawa Y, et al. Assessment of indomethacin oral spray for the treatment of oropharyngeal mucositis-induced pain during anticancer therapy. Support Care Cancer. 2017;25:2997-3000.

22. Ling IS, Larsson B. Individualized pharmacological treatment of oral mucositis pain in patients with head and neck cancer receiving radiotherapy. Support Care Cancer. 2011;19:1343-50.

23. Gligorov J, Bastit L, Gervais H, et al. Prevalence and treatment management of oropharyngeal candidiasis in cancer patients: results of the French CANDIDOSCOPE study. Int J Radiat Oncol Biol Phys. 2011;80:532-9.

24. Davies AN, Brailsford SR, Beighton D. Oral candidosis in patients with advanced cancer. Oral Oncol. 2006;42:698-702.

25. Wilberg P, Hjermstad MJ, Ottesen $\mathrm{S}$, et al. Oral health is an important issue in end-of-life cancer care. Support Care Cancer. 2012;20:3115-22.

26. Rydholm M, Strang P. Physical and psychosocial impact of xerostomia in palliative cancer care: a qualitative interview study. Int J Palliat Nurs. 2002;8: $318-23$.

27. Rohr Y, Adams J, Young L. Oral discomfort in palliative care: results of an exploratory study of the experiences of terminally ill patients. Int J Palliat Nurs. 2010;16:439-44.

28. Ezenwa MO, Fischer DJ, Epstein J, et al. Caregivers' perspectives on oral health problems of end-of-life cancer patients. Support Care Cancer. 2016; 24:4769-77.

29. Tebidze N, Jincharadze M, Margvelasvili V. Oral complications of palliative patients with advanced cancer. Transl Clin Med - Georg Med J. 2017;2:20-3.

30. Mulk BS, Chintamaneni RL, Mpv P, et al. Palliative dental care- a boon for debilitating. J Clin Diagn Res. 2014;8:ZE01-6.

31. Chen X, Kistler CE. Oral health care for older adults with serious illness: when and how? J Am Geriatr Soc. 2015;63:375-8.

32. Lalla RV, Sonis ST, Peterson DE. Management of oral mucositis in patients who have cancer. Dent Clin N Am. 2008;52:61-77 viii.

33. Chung JP, Mojon P, Budtz-Jørgensen E. Dental care of elderly in nursing homes: perceptions of managers, nurses, and physicians. Spec Care Dentist. 2000;20:12-7.

\section{Publisher's Note}

Springer Nature remains neutral with regard to jurisdictional claims in published maps and institutional affiliations.

Ready to submit your research? Choose BMC and benefit from:

- fast, convenient online submission

- thorough peer review by experienced researchers in your field

- rapid publication on acceptance

- support for research data, including large and complex data types

- gold Open Access which fosters wider collaboration and increased citations

- maximum visibility for your research: over $100 \mathrm{M}$ website views per year

At BMC, research is always in progress.

Learn more biomedcentral.com/submissions 